Lecca P, Swales JK \& Turner K (2011) An investigation of issues relating to where energy should enter the production function, Economic Modelling, 28 (6), pp. 2832-2841.

This is the peer reviewed version of this article

NOTICE: this is the author's version of a work that was accepted for publication in Economic Modelling. Changes resulting from the publishing process, such as peer review, editing, corrections, structural formatting, and other quality control mechanisms may not be reflected in this document. Changes may have been made to this work since it was submitted for publication. A definitive version was subsequently published in Economic Modelling, [VOL 28, ISSUE 6,(2011)] DOI: http://dx.doi.org/10.1016/j.econmod.2011.08.014 


\title{
An investigation of issues relating to where energy should enter the production function
}

By

\author{
Patrizio Lecca ${ }^{1}$, Kim Swales ${ }^{1}$ and Karen Turner ${ }^{2 *}$
}

1. Fraser of Allander Institute and Department of Economics, University of Strathclyde

2. Division of Economics, Stirling Management School, University of Stirling

* Corresponding author: Dr Karen Turner, Division of Economics, Stirling Management School, University of Stirling, Cottrell Building, Stirling, FK9 4LA, Scotland, UK; Phone: +44 (0)1786 467474; karen.turner@stir.ac.uk

ACCEPTED FOR PUBLICATION IN ECONOMIC MODELLING AUGUST 2011

\section{Acknowledgements}

The research reported here has been funded by the UK Economic and Social Research Council, ESRC, through the First Grants Initiative (ERSRC grant reference RES-061-250010). It also builds on previous and related research on modelling energy use and supply funded by the UK Engineering and Physical Sciences Research Council, EPSRC, through the SuperGen Marine Energy Research Consortium (Grant reference: EP/E040136/1). The authors would like to thank Harry Saunders (Decision Processes Incorporated, California) for comments on an earlier version of this paper. We are also grateful to two anonymous referees for comments on the initial submission of the paper. 


\section{An investigation of issues relating to where energy should enter the production function}

\section{Abstract}

This paper examines the impact of imposing different separability assumptions in the specifications of the standard hierarchical KLEM production function in a computable general equilibrium (CGE) model. The appropriate means of introducing energy to production functions has been a source of debate for a number of years. However, while modellers often subject results to parametric sensitivy analysis regarding the values associated with elasticities of substitution between inputs, it is rarely the case that the structure of the production function is subjected to testing. However, the chosen structure reflects the modeller's view about elasticity between different inputs and will have implications for model results wherever there are changes in relative prices. We illustrate our argument by introducing a simple demand shock to a CGE model of the Scottish economy (targeted at the energy supply sector) under different assumptions regarding the structure of the KLEM production function and separability assumptions therein.

Keywords: general equilibrium, KLEM production function, separability assumptions.

JEL codes: C68, D57, D58, R15, Q41, Q43 


\section{Introduction}

The appropriate specification of nested production functions in computable general equilibrium (CGE) models, and associated use of 'separability assumptions', is historically a source of debate in the literature (see, for example, Hertel and Mount, 1985; Despotakis and Fisher, 1988; Li and Rose, 1995; Naqvi, 1998). In particular, the debate focussed on the specification of KLEM functions, which incorporate and distinguish capital, labour, energy and material inputs, with specific focus on how energy should combine with other inputs. Energy CGE models have become increasingly commonly used, for example in the energy efficiency and rebound literature (Glomsrød and Wei, 2005; Grepperud and Rasmussen, 2004; Turner, 2009; Wissema and Dellink, 2007). However, while parametric sensitivity analyses of CGE model results may be conducted, these tend not to include consideration of alternative structures in the production function This paper aims to reawaken the debate regarding the importance of separability assumptions by focussing on the impact of varying the structure of the production function itself; that is the manner in which energy is introduced as an input to production.

The empirical analysis in this paper (using a CGE model of the Scottish economy as an illustrative case) focuses on introducing a very simple change in economic activity that would be expected to have a short-run impact on relative input, especially energy, prices in the KLEM production function. We then examine the sensitivity of key results to alternative nestings of the KLEM production function, with particular attention to the point at which energy enters. Moreover, the simulation is designed to produce changes in prices that are transitory so to allow us to confirm that the particular nesting of the production function only matters relative prices change. 
The specific simulation involves introducing a disturbance to export demand for the outputs of the (relatively energy intensive) Scottish energy supply sectors. A simple demand disturbance is used because, in the absence of any lasting constraints on supply, the CGE simulations should produce input-output type results over the long-run, with prices returning to their pre-shock levels (McGregor et al., 1996). We further simplify by assuming the nominal price of labour is determined exogenously (e.g. a national bargaining scenario in the regional model). This makes the supply of labour completely elastic while capital supply is completely inelastic in the short run. This implies that the source of all price changes is variation in the capital rental rate up to the point where capital stocks are fully adjusted in response to the shock.

Thus, with no long-run run change in relative input prices, the impact on macroeconomic variables should be the same regardless of the nesting of the production function. The model confirms these results. However, the short-run impact is sensitive to the particular nesting of the production function. More generally, we would only expect differing price elasticities between inputs, either directly imposed or implied by the nesting of the production function, to matter where relative prices change. Thus, the sensitivity of results to the nesting of the production function, and elasticities imposed therein, observed here in the short-run would be expected over the longer run where there is a lasting impact on relative prices. This would occur, for example, in the presence of supply constraints and/or increased efficiency in the use of any input to production.

The remainder of the paper is structured as follows. We begin by reviewing the relevant literature concerning the introduction of energy as an input to production through nested 
KLEM production functions in a CGE context. We then outline the Scottish CGE model before discussing the results of simulating a simple (export) demand shock targeted at the domestic energy supply sector under different specifications of the KLEM production function. The final section provides a summary and conclusions.

\section{The introduction of energy to KLEM nested production functions}

Berndt and Wood (1975) noted that industrial energy demand is a derived demand initiated in the production process. This implies that, as with other inputs, industrial energy demand from a particular sector is dependent on the level of output, relative prices and the degree of technical flexibility. For this reason many analysts have sought to identify the appropriate technology for combining energy with other production inputs (e.g. Griffin and Gregory, 1976; Berndt and Wood, 1979; Morrison and Berndt, 1981; Pindych and Rotemberg, 1983; Solow, 1987). Flexible functional forms are sometimes used in CGE models in the form of cost functions, as the dual to the production function. For example, Despotakis and Fisher (1988) and Li and Rose (1995) use Generalised Leontief, and Hertel and Mount (1985) a Translog cost function in their regional energy/environmental CGE models.

However, the use of nested CES production functions has become more common in studies that use capital, labour, energy and materials in the so-called KLEM production functions (e.g. Prywes, 1986; Chang, 1994; Kemfert, 1998; Kemfert and Welsch, 2000 and Kuper and Van Soest, 2002). Nested CES production functions (with Cobb-Douglas, CD, and Leontief technology used as special cases where elasticities of substitution are set at 1 or 0 respectively) are commonly used in CGE models in general (see Perroni and Rutherford, 1995), and specifically in energy/environmental CGE models, whether these are 
global/international models (e.g. Beghin et al, 1995; Beauséjour et al, 1995), national level models (e.g.; Böhringer and Rutherford, 1997; Naqvi, 1998; Stephan et al, 1992) or, regional applications (e.g. Anson and Turner, 2009; Kamat et al, 1999; Turner, 2009).

The key characteristic of nested CES production functions is that each nest consists of an individual production function where the elasticity of substitution is the same regardless of factor proportions and scale. For any one CES relationship, the elasticity of substitution must be the same among all factors. Appropriate nesting of CES relationships within a hierarchical structure is used to enhance the flexibility of the CES function. For example, in the threeinput case of capital, labour and energy inputs, this can look like Figure 1. Using such a hierarchical production function means that the elasticity of substitution between inputs, usually pairs, combined in different nests (levels) potentially differ. For example, in Figure 1, the value of the elasticity of substitution between capital and energy ( $K$ and $E$ ) in the capitalenergy composite input (or nest) is $\sigma_{\mathrm{KE}}$, while the elasticity of substitution between this composite and labour is $\sigma_{\mathrm{L}(\mathrm{KE})}$. The nesting allows these elasticities to differ.

\section{[Insert Fig 1 around here]}

However, this type of nested production structure still retains a degree of inflexibility in that it requires the imposition of separability among the inputs. This separability argument is concerned with the fact that CES production functions usually only allow substitutions between pairs of inputs at any level in the hierarchy. ${ }^{1}$ At least one of these inputs typically is

\footnotetext{
${ }^{1}$ Of course it is possible to have more than two inputs at any one level of a nested CES function. However, as shown by Uzawa (1962), where there are more than two inputs the elasticity among all inputs must be the same or, if any differ, these must all equal each other and the remaining elasticities must be unity. For this reason, it is commonly the case that only two inputs will combine at any one level of a nested CES function. However, different nesting schemes will represent different assumptions about substitution behaviour.
} 
a composite input resulting from substitution between another pair of inputs at a lower level (e.g. KE in Figure 1). This has the implication that both of the inputs incorporated in the composite must substitute equally well for the third input (e.g. in Figure 1 capital and energy must both substitute equally well for labour).

Such 'separability' assumptions could lead to important substitution effects being lost. Specifically, again using Figure 1 as an example, any adjustment in the capital-energy input ratio in response to a change in the price of labour that is attributable to differences in the relative substitutability of capital or energy for labour will not be captured. For this reason Hertel \& Mount (1985), Depotakis \& Fisher (1988) and Li \& Rose (1995) argue that it is more appropriate to adopt some type of flexible functional form production function. ${ }^{2}$ The idea is to make the production function as flexible as possible by minimising the number of prior assumptions about its form. Adkins et al (2003) consider the recommendation of Partridge and Rickman (1998), who cite and question the dominance of the nested CES approach in regional CGE models, in using a Bayesian framework to estimate Translog cost functions to consider own- and cross-price elasticities between different capital, labour and energy. They then compare the results of CGE model simulations based on the results to a more standard Cobb-Douglas specification.

While the basic idea of making the production function as flexible possible by minimising the number of prior assumptions about its form is a valid one, the argument over whether to use nested CES or flexible functional forms such as translog is likely to boil down to a trade off between flexibility and tractability. In a model with a highly detailed treatment of energy, Naqvi (1998) argues that, where there are multiple inputs and/or multiple sectoral outputs,

\footnotetext{
${ }^{2}$ Hertel (1988) demonstrates the separability argument analytically using a 2-sector model with 3 primary factors.
} 
separability assumptions are necessary from a practical point of view. Indeed, Hertel and Mount (1985), Depotakis and Fisher (1988) and Li and Rose (1995) all choose to employ two-level production functions.

However, as Adkins et al (2003) argue, a combination of the two approaches may be used, with the results of estimation of more flexible translog cost functions used to inform CES substitution parameters. In an earlier study, Griffin and Gregory (1976) estimate translog functions then translate the results to elasticity of substitution parameters for capital-labour, capital-energy and labour-energy combinations for eight European countries and the US. The fit of results for alternative pairwise combinations may help CGE modellers decide which inputs should combine directly at different CES nests, but does not give a measure of the overall structure. To address this problem, Kemfert (1998) attempts to estimate appropriate nesting between of a CES KLEM structure for different production sectors in the German economy. Van der Werf (2008) extends to more countries and production sectors but, due to data limitations, is able to estimate at only country or industry level (i.e. not industries within countries). Moreover, both of these studies limit their attention to the capital, labour and energy inputs, ignoring non-energy intermediates, or materials.

Generally, in the absence of econometric estimates to inform appropriate nesting structures, and where it is not practical to estimate and employ more flexible specifications of production functions, it would seem appropriate to test for the impacts of adopting different separability assumptions. Sensitivity analysis for key parameter values is commonly carried out in CGE modelling applications, and this can be done quite systematically to provide interval estimates for the consequences of different types of disturbance - see, for example, Borges and Goulder, 1984; Conrad, 1999; Turner, 2009. However, the CGE modelling 
literature lacks any attempt to test the sensitivity of results to different specifications of hierarchical production functions. Indeed, there is an absence of any explicit discussion of why energy would enter at different levels of the production function. The aim of the current paper is to make a first step in redressing this gap in the literature by considering the sensitivity of the results of an illustrative demand shock to two alternative hierarchical specifications of the CES KLEM production function. These two specifications are first where energy is introduced to first the intermediates block and second as a direct substitute for capital in the value-added block. The simulations are performed using a CGE modelling framework parameterised on Scottish data.

\section{General model description}

In this paper we develop the AMOSENVI CGE modelling frameworks of the Scottish economy that has been employed in our previous research (Anson and Turner, 2009; Hanley et al., 2006, 2009). AMOSENVI is the energy-economy-environment version of the basic AMOS CGE framework developed by Harrigan et al (1991). ${ }^{3}$ Condensed descriptions/equation listings of the Scottish AMOSENVI model can be found in Hanley et al (2009). ${ }^{4}$ Here, we focus on the novel elements of model specification applied in this paper.

\footnotetext{
${ }^{3}$ AMOS is an acronym for A micro-macro Model Of Scotland, deriving its name from the fact the framework was initially calibrated on Scottish data.

${ }^{4}$ SCOTENVI is calibrated to a 1999 SAM for Scotland (see, e.g., Hanley et al, 2009). The current model has six economic activities or sectors separately identified: Primary (PRI) sector, Manufacturing (MAN), Construction (CON), Services (SER), Public and Recreational Services (PSER) and Energy Production (ENE) (see Appendix 1 for sectoralclassifications).Previous applications of the AMOSENVI modelling framework typically have a greater degree of sector disaggregation. The current model is limited to six production sectors to allow us to solve for the complex variation in the hierarchical production structure. However, we aim to reintroduce more sectoral disaggregation in future applications.
} 
We develop the Scottish model to allow a more flexible treatment of energy as an input to production, allowing simulation with two alternative nested KLEM production functions. These are shown in Cases A and B in Figure 2. Note that it is possible to specify further alternative production functions, for example, with energy entering at the same nest as labour instead of capital (in Case B), or at a higher nest, combining with the labour-capital valueadded composite.

One crucial point to note here is that in any of the KLEM production functions we specify in AMOSENVI Energy is treated as a produced input. That is, energy is the output of the Scottish Energy Production (ENE) sector and of the corresponding rest of UK (RUK) and rest of the world (ROW) sectors from which Scottish producers and final consumers import. This is an important point as it means that changes in local energy supply prices resulting from variations in capacity and transport costs can be identified (Anson and Turner, 2009). It may also explain why some authors would select the type of KLEM production structure shown in Case A, where Energy enters the intermediate rather than primary input block of the nested production function. An example is Beauséjour et al (1995), who distinguish energy from natural resources, which are treated as primary inputs alongside value-added.

Households, Firms and Government are the three domestic institutional sectors. Households' and firms' behaviour are the result of an optimization process with myopic expectations; Government real consumption is held constant in the current application (though this can be endogenised). The external institutions are divided into RUK and ROW. Since Scotland is too small for any price effects in international market to feed back to the target economy, we adopt assumptions typically used for a small open economy in that ROW prices are taken to 
be exogenous. Within the UK, we assume that Scotland is a price taker in all markets so that RUK prices can also be taken as exogenous.

Intermediate, capital and consumption goods produced locally and imported are considered as imperfect substitutes. Scottish regional goods combine with imported goods under the so called Armington assumption (Armington, 1969) through a CES function (see below).

The outputs of Scottish production sectors are purchased by industries and by domestic and external final consumers. Each industry in the region produces commodities that can be exported or sold in the regional market. An export demand function closes the model where external demand is sensitive to changes in relative prices between domestic and external prices.

Labour and capital stocks are fixed in the short-run, which (given the time period covered by the SAM) we take to be the first year after a disturbance is introduced. Thereafter, adjustment is made to long-run equilibrium, where both labour and capital stocks are fully adjusted.

Within each period, both the total capital stock and its sectoral composition are fixed. Each sector's capital stock is then updated between periods via a simple capital stock adjustment procedure, according to which investment equals depreciation plus some fraction of the gap between the desired and actual capital stock. The desired capital stock is determined on costminimisation criteria and the actual stock reflects last period's stock, adjusted for depreciation and gross investment. The economy is assumed initially to be in long-run equilibrium, where desired and actual capital stocks are equal. 
Population updating is incorporated through a migration function of the Harris and Todaro (1970) type, and parameterised on UK econometric work by Layard et al. (1991). We assume that there is no natural population change but labour forces adjust through migration, where in any period the decisions of migrants are positively related to the gap between regional, Scottish, and national, UK, real wages, and negatively related to the gap between national and regional unemployment rates.

\section{Alternative nested production functions}

\section{[Insert Figure 2 around here]}

The model adopts the general KLEM (Capital, Labour, Energy and Material) production structure allowing for substitution between KLEM inputs in different levels. Two options for the model's hierarchical production structure are illustrated in Figure 2, where two possible hierarchical structures are distinguished as Case A and Case B. Both cases are examples of multilevel (nested) CES production functions. However, energy is introduced at different levels of the hierarchy in the different variants. The typical nested production function combines at its top level a value-added and an intermediate composite. In separately identifying (or focussing on) energy, there are two choices: (a) which composite should it join?; (b) how should energy be incorporated in that composite?

Note that in the empirical analysis below, where Case A or Case B is adopted, we assume that this production function applies to all six sectors. Within each case, it is possible to vary the elasticity at each nest across sectors. However, for simplicity we hold the structure constant across sectors in the analysis presented here. 
In Case A, illustrated in Figure 2, energy is positioned with the other intermediates input allowing for substitution between energy and non-energy (or materials) in the intermediate composite input. Specifically, we assume Leontief technology in the combination of all nonenergy intermediates, but with substitutability between domestic and imported materials composites. Capital and labour combine in the value-added composite. Output is then produced by the combination of these two composites (EM+KL).

In Case B, also illustrated in Figure 2, energy enters the value-added nest. Specifically, energy combines with capital and the resulting composite is then combined with labour $(\mathrm{EK}+\mathrm{L})$. The KLE composite then combines with materials in the upper nest to produce sectoral output (in a CES relationship). As noted above, it would be possible to have energy enter in a single nest with labour and capital (e.g. Glomsrød and Wei, 2005), combining first with labour only (though we found no CGE examples with this treatment), or with a labourcapital composite (e.g. Stephan et al, 1992; Böhringer \& Rutherford, 1997; Zhang, 1998). Case $\mathrm{B}$ is chosen here because of the importance attached to energy-capital substitutability/complementarity in the literature. For key early contributions in this debate, see Field and Berndt (1981), Berndt and Wood (1975) and Griffin and Gregory (1976). Bergman (1988) surveys different CGE approaches, while Despotakis and Fisher (1988), in specifying their regional CGE model for California, revisit the debate in the context of the differing nature of capital and its substitutability with energy and other inputs over the short versus the long run. Since then, where energy enters the value-added block, CGE modellers have tended to distinguish the energy-capital combination in a separate nest (e.g. Beghin et al, 1995; Kamat et al, 1999; Grepperud and Rassmussen, 2004), sometimes combining with other natural resources (e.g. Bergman, 1990, 1991; Burniaux et al, 1992). Beauséjour et al 
(1995) also introduce natural resources to the value-added block. However, as noted above, in distinguishing energy as a produced input, they introduce it to the intermediates block as in Case A here.

Here, in both Case A and Case B, energy inputs are a combination of first locally produced energy and energy imported from the rest of the UK, RUK, and then between the UK composite and energy from the rest of the world, ROW. The Armington elasticity of import demand in all cases is set at the value of 2.0, as is the price elasticity of export demand for the outputs of all sectors (Gibson, 1990). ${ }^{5}$ This treatment of imports extends and improves on that in previous applications of the AMOSENVI framework, where a composite of locally produced intermediate inputs (energy and materials) combines with composite imports. Similarly, in both cases, the local materials composite is a Leontief composite of the outputs of local production sectors, combined with imported materials composites (from each of the external transactors, first RUK, then ROW) using the Armington CES function, again with a value of 2.0 .

\section{Simulating a demand-side shock under different specifications of the KLEM production function}

We simulate an illustrative one-off $10 \%$ step increase in export demand from the rest of the UK (RUK) for the outputs of the Scottish Energy sector. That is, RUK export demand rises by $10 \%$ in year one of the simulation and is maintained at the higher rate throughout. While this particular export demand shock is used simply for illustrative purposes, such a demand

\footnotetext{
${ }^{5}$ See Turner $(2008,2009)$ for a comprehensive sensitivity analysis of the importance of both import and export elasticities in governing the impacts of an increase in efficiency in the use of energy in production in the Scottish and UK economies.
} 
shock is possible, for example given that Scotland exports electricity to other UK regions through the interconnector system.

As explained in the previous section, the results reported in the paper focus on two cases: Case A, where energy enters the intermediates block, and Case B, and where it enters the value-added block combining first with capital. This is sufficient to demonstrate that the point of entry is important. In each case the impact of varying elasticities of substitution at three nests of the production function are tested (indicated with arrows in Figure 2), with summary results of each of these reported in Tables 1-3 for Case A and Tables 4-6 for Case B. For example, Table 1 gives the changes in key economic variables as the values of the elasticity of substitution between $\mathrm{K}$ and $\mathrm{L}$ is varied in Case $\mathrm{A}$. In all cases the default/central value for all elasticities of substitution in production is taken to be 0.6. Elasticities of substitution between imported energy and materials are assumed to take the value of 2.0 throughout and are not subject to sensitivity analysis (see Turner, 2008, 2009). A key point to note is that the prices of import goods are exogenous and therefore fixed, so that any relative price change arises from changing prices of capital, labour and domestically produced energy and materials.

In an initial base run of simulations (shown in the 0.6 column of Tables 1-3 for Case A and Tables 4-6 for Case B) we confirm that if all elasticities of substitution in the nests where capital, labour, energy and material combine are set at the same value the results are not sensitive to the choice of the KLEM production function between Cases A and B. This base case was run for a wider set of production function specifications, not reported here, but the simulations confirmed the same outcome. This is because the CES functions for these nests effectively collapse to a single nest with a single elasticity of substitution between all four 
inputs. Essentially, this result simply highlights the fact that the hierarchical structure of the nested production function allows for variation in the degree of substitution between inputs. However, where such variation is not imposed, the nested structure is irrelevant.

The next question, then, is what happens if different values are imposed at different levels of the nest? We begin by taking Case A, the KLEM specification assumed in previous applications of AMOSENVI, where energy enters the production function through the intermediates block (i.e. combining first with materials). The lower and upper values for the elasticity of substitution at the different KLEM nests are taken to be 0.2 and 1.2. These are the E-M, EM-LK and L-K nests in Figure 2.A. The default value is 0.6 in all three nests. The elasticity at each nest is then varied in turn across this range. Thereafter, the same procedure is repeated for Case B, where energy is introduced as a direct substitute for capital in the value-added nest.

In these simulations, we relax all long-run supply constraints. That is, we allow both capital and labour stocks to fully adjust in the long run. Given linear homogenous production functions and our migration and investment assumptions, this implies that there is no longrun impact on input prices from the exogenous demand shock. Here we report the short-run the first period (year) after the demand shock is introduced, where labour and capital stocks are fixed, and the long-run, once labour and capital stocks are fully adjusted. It would be possible to report period-by-period results to track the adjustment process. However, for simplicity, we focus on the short- and the long-run. The economy is taken to be in long-run equilibrium prior to the demand disturbance, so that when the model is run in the absence of any disturbance it simply replicates the initial equilibrium. The results reported in Tables 1-6 and Figures 3-6 refer to percentage changes in the endogenous variables relative to this 
unchanging equilibrium. Thus, all of the reported effects are directly attributable to the exogenous export demand stimulus to the Energy sector.

Long-run results (all cases)

[Insert Tables 1-3 around here]

It is useful to consider the long-run results first. Given that all supply constraints are relaxed in the long-run, there is no change in prices over this time interval. This implies that there is no long-run change in the cost minimising supply techniques reported in the simulation results given in the final column of Tables 1-6. The long-run results replicate extended demand-driven input-output results (McGregor et al, 1996) and are independent of elasticity values or the nature of the production structure. In all of the cases reported in Tables 1-6, the results show that the long-run impacts of the external demand shock are a boost in GDP $(0.28 \%)$, investment $(0.32 \%)$, employment $(0.19 \%)$ and household consumption $(0.13 \%)$. Activity (and capacity) levels are boosted in all sectors, particularly the Energy sector as the direct recipient of the stimulus (where capital stocks and employment both rise by $3.8 \%$ ). In the long-run, with no constraints on supply (so that the general equilibrium supply curve becomes horizontal in the long-run, though the demand curve remains downward sloping), there is no lasting impact on prices anywhere in the system, with the result that the simulated impact is not sensitive to the values assigned to elasticities of substitution imposed at each nest in the production function.

\section{[Insert Tables 4-6 around here]}


However, in the short run, where capital stocks are fixed in each sector and total labour supply is fixed (though workers can move between sectors and employment can change through changes in the unemployment rate), there is crowding out of activity and prices of all inputs are pushed up. The increase in the real wage rate is limited by the presence of a pool of unemployed labour, while the capital rental rate increases more significantly, particularly in the Energy sector where the demand stimulus is targeted and where production is capital intensive. The price of the local intermediates (EM) composite is pushed up depending on (a) how energy-intensive production is and (b) the ratio of locally supplied intermediates (where prices are rising) to imports (where prices are exogenous).

However, the extent of short-run crowding out also depends on how easily production sectors can substitute between inputs, and the relative substitutability of different inputs. We focus our analysis on the sensitivity of GDP (Figures 3 and 5) and total energy use in production (Figures 4 and 6) to the variation in substitution possibilities.

\section{[Insert Figure 3 around here]}

First, Figure 3 shows the impact on the change in GDP when we vary the value imposed on the elasticity of substitution between $\mathrm{E}$ and $\mathrm{M}, \mathrm{EM}$ and $\mathrm{LK}$, and $\mathrm{L}$ and $\mathrm{K}$ in turn (where 0.6 is taken as the default value on parameters not being tested in each case). Three basic points can be made. First, all the curves go through the same point when all elasticities of substitution are set at 0.6. Second, the variation in results as the elasticity of substitution varies at different points of the production function differs not just in magnitude but also in sign. 
Third, the biggest (and positive) variation in the change in GDP comes through changes in the elasticity of substitution between capital and labour. This is because capital is fixed in the short run (total labour stocks are also; however, there is a pool of unemployed labour that firms may draw on). As this elasticity increases it is easier for producers to substitute labour for fixed capital. This limits the increase in the capital rental rate in the energy sector as more labour moves into the Energy sector, allowing greater expansion in response to the increase in export demand (the opposite is true in the non-energy sectors not directly impacted by the demand shock).

On the other hand, the size of the GDP impact is negatively related to the value of the EMLK parameter. The percentage increase in the price of value added is considerably greater in all cases than the price of intermediates, with the implication that the more substitutable intermediates are for value-added, there is greater substitution away from the latter in the short-run (though, within the intermediates block there will also be substitution away from domestic production in favour of imports - see below). In terms of the point where energy enters the production function (the issue that is the cause of much debate in the literature), here where the energy composite combines with materials in the intermediates block, Figure 3 highlights the fact that this parameter has little impact on the results for the aggregate indicator of GDP.

Indeed examination of Table 3 shows that the value of the elasticity at the E-M nest has an almost imperceptible impact on the main economic indicators. The substitution of other, nonenergy intermediates has a small aggregate effect because this process is only off-setting a small increase in total costs (given that energy is generally only accounts for a small share of total inputs). 
Varying the elasticity at the E-M nest has the most impact on the use of energy in production. However, given the increase in the price of locally produced energy has risen (driving up the composite price of energy) means that there is substitution in favour of (a) imported energy, the supply of which is elastic, and (b) non-energy intermediates (M), the local supply of which, as with local energy, is affected by the short-run fixity of labour and capital. The latter has the implication that the increase in production use of composite energy and of local energy is negatively related to the size of the elasticity of substitution between $\mathrm{E}$ and $\mathrm{M}$, while the former has the implication that use of RUK energy is positively related to the value of this parameter. The increase in imports of ROW energy decline as this parameter increases because of the smaller increase in the price of composite UK energy as there is more substitution away from local towards other UK energy. It is important to note that this result is a function of the way imported and domestic energy have been nested in the KLEM production function.

\section{[Insert Figure 4 around here]}

Nonetheless, Figure 4 highlights the fact that the energy use in production (as with total energy use) in response to the demand shock simulated here is not hugely sensitive to the value imposed on the E-M parameter. On the other hand, total energy use in production is more sensitive (and positively related) to the substitutability between intermediates and value-added (EM-KL), given that the price of the KL composite has risen by more (due to the increase in the capital rental rate). Similarly, energy use in production is also more sensitive to the substitutability between labour and capital, where there is some excess capacity in the 
case of labour allowing greater adjustment in production activity the short-run the easier it is to substitute in favour of labour.

Short-run results: Case B Energy in value-added $(L+K E)$

Next, we examine same exogenous demand shock under an alternative specification of the nested production function. We take Case $\mathrm{B}$, where energy is introduced to the production function as a direct substitute for/linked to capital. Again, the default elasticity of substation at the different nests where the KLEM inputs combine is 0.6. These are E-K, EK-L and LEK-M nests in Figure 2. The elasticity at each nest is then varied in turn across the range 0.2 to 1.2 .

\section{[Insert Figure 5 around here]}

Generally, introducing energy at the same nest as capital has quite different impacts in the short-run. Figure 5 examines the relative impacts of varying the elasticities at the different nests of both production functions A and B on the change in Scottish GDP as a result of the demand shock to the Energy sector. This figure shows that the value attached to the elasticity of substitution at the point where energy enters the production function (which, at the E-M nest was the least important parameter tested in case Case A) now becomes a much more important parameter (the E-K parameter in Case B). Figure 5 shows the GDP results remain most sensitive to the K-L substitutability in Case A. However, Table 5 and Figure 5 demonstrate that in Case B the elasticity with which energy combines directly with the fixed input capital (represented by the unmarked line in Figure 5) is very influential on the results for this and other macroeconomic indicators. The capital rental rate rises markedly, as does 
the price of locally produced Energy and the energy composite overall, but by less as the substitutability in favour of energy and away from (at this point) fixed capital grows (given the fixity of capital, this substitution away from capital allows output to rise by more).

Moreover, Table 5 shows that as the substitutability in favour of energy as an input rises, the E-K parameter has the greatest positive impact on production use of energy (across both Cases A and B) and least negative impact on final consumption use of locally produced energy. The case of production use of energy is highlighted in Figure 6.

\section{[Insert Figure 6 around here]}

Table 5 also shows that growth in all of the macroeconomic indicators, and all types of energy use are positively related to the value of the elasticity at the E-K nest. On the other hand, comparison with Table 4 shows that the greater the substitutability in favour of labour (which is not entirely constrained, given the presence of unemployed labour in the base year) and away from the EK composite (with its fixed component) there is greater GDP growth, but smaller increases in energy use. However, as highlighted in both Figures 5 and 6 below, generally the model results are less sensitive to the value of the elasticity of substitution between $\mathrm{KE}$ and $\mathrm{L}$ than between $\mathrm{K}$ and $\mathrm{E}$. This is particularly the case with respect to production use of energy in Figure 6, where we see that the EK-L parameter has the least impact in Case B and only slightly more impact than the E-M parameter in Case A.

However, the key point to note in Figure 6 is that while total use of energy in production is least sensitive to the E-M parameter where energy enters the production function in Case A, 
the $\mathrm{E}-\mathrm{K}$ parameter (where energy enters in Case B) is the most important determinant of energy use in production tested here.

In Table 7, we offer an additional set of sensitivity analysis. In contrast to the systematic variation of elasticity values at each nest in Case A and Case B, in Table 7, we report the results of random variation across a subset of 1000 possible values at each nest (across the range 0.2-1.2 applied above). Here, we see that more slightly more variation (indicated by the standard deviation, SD) in results is observed for GDP in Case A, where energy enters as an intermediate, but this is very slight (standard deviation of 0.065 compared to 0.062 in Case B). However, it is clear that the nested production function in Case $\mathrm{B}$, where energy enters to combine directly with capital, provides a great deal more variability in results for the change in energy use in production, with a standard deviation of 0.311 compared to 0.167 in Case A. ${ }^{6}$

\section{Conclusions}

The key finding in our analysis is that, as well as the magnitudes of the substitution elasticities, the point at which energy enters the production function has a significant impact on CGE model results. However, this is only where there are (a) differences in elasticities at different nests; (b) relative price changes. While this is reflected in only the short-run results of the demand disturbance examined here, it is important to note that if a lasting supply constraint were imposed on either labour or capital, the long-run equilibrium of the economy would also be affected by the nesting structure. Generally, the elasticity of supply of different inputs is important in the context of alternative nesting structures. As demonstrated in the

\footnotetext{
${ }^{6}$ While it is not reported here, we find that the standard deviation is higher in othercases where energy enters to combine with value-added more generally - i.e. combining directly with labour or with a labour-capital composite
} 
analysis presented here, where energy is introduced at the same nest as another input whose supply is inelastic, the elasticity of substitution at this nest becomes more important in determining the results of simulating a change to the demand for or supply of energy.

Thus, the analysis in this paper demonstrates that introducing energy at different points in the KLEM nested production function does have implications for the stability of results. This implies that modeller judgement with respect to substitution possibilities between different inputs is crucial. Therefore, a priority for modellers employing KLEM production functions must be to investigate whether it is possible to econometrically estimate the appropriate parameter values and/or structure in economy- and industry-specific production functions.If econometric estimation is not possible, sensitivity analysis should be applied not only to parameter values but also nesting structures. Most CGE studies, often considering issues such increased energy efficiency which will have lasting supply-side impacts neither econometrically specify production function relationships nor conduct comprehensive sensitivity analyses of nesting choices. Our analysis suggests that this is likely to have serious implications in terms of the reliability of results.

\section{References}

Adkins, L.C., Rickman, D.S. and Hameed, A. (2003). "Bayesian estimation of regional production for CGE modelling." Journal of Regional Science 43: 641-661.

Anson, S. and Turner, K. (2009). "Rebound and disinvestment effects in refined oil consumption and supply resulting from an increase in energy efficiency in the Scottish commercial transport sector." Energy Policy 37: 3608-3620. 
Armington, P. (1969). "A theory of demand for products distinguished by place of production.” IMF Staff Papers, 16: 157-178.

Beauséjour, L., Lenjosek G. and Smart, M. (1995). “A GCE Approach to Modelling Carbon dioxide emissions control in Canada and the United States." The World Economy 18: 457489.

Beghin, J., D. Roland-Holst and Mensbrugghe, D. (1995). "Trade Liberalisation and the Environment in the Pacific Basin: Coordinated Approaches to Mexican Trade and Environmental Policy.” American Journal of Agricultural Economics 77: 778-785.

Bergman, L. (1988). "Energy Policy Modelling: a Survey of General Equilibrium Approaches." Journal of Policy Modelling 10: 377-399.

Bergman, L. (1990). "Energy and Environmental Constraints on Growth: a CGE Modelling Approach” Journal of Policy Modelling 12: 671-691.

Bergman, L. (1991). "General Equilibrium Effects of Environmental Policy: a CGE Modelling Approach.” Environmental and Resource Economics 1: 43-61.

Berndt, E.R., Wood, D. (1975). "Technology, prices, and the demand for energy." The Review of Economics and Statistics 57: 259-268.

Berndt, E.R, Wood D. (1979). 'Engineering and econometric interpretations of energycapital complementarity." American Economic Review 69: 342-354. 
Böhringer, C. and Rutherford, T. (1997). "Carbon taxes with exemptions in an open economy: a general equilibrium analysis of the German tax initiative." Journal of Environmental Economics and Management 32: 189-203.

Borges, A.M. and Goulder, L.H. (1984). "Decomposing the impact of higher energy prices on long-term growth." in H.E. Scarf and J.B. Shoven eds. Applied General Equilibrium Analysis. Cambridge University Press.

Burniaux, J-M., J. P. Martin, G. Nicoletti and J. M. Martins (1992) "Green. A Multi-Sector, Multi-Region General Equilibrium Model for Quantifying the Costs of Curbing CO2 Emissions: a Technical Manual." OECD Economics Department Working Papers, No.116. OECD, Paris, 1992.

Chang K.P. (1994). "Capital-energy substitution and the multi-level CES production function." Energy Economics 16: 22-26.

Conrad, K. (1999) "Computable general equilibrium models for environmental economics and policy analysis." in J.C.J.M. van den Bergh ed. Handbook of Environmental and Resource Economics. Edward Elgar Publishing Ltd.

Despotakis, K.A. and Fisher, A.C. (1988). "Energy in a regional economy: a computable general equilibrium model for California." Journal of Environmental Economics and Management 15: 313-330.

Field, B.C. and E.R. Berndt (1981) Modelling and Measuring Natural Resource Substitution. MIT Press, 1981. 
Gibson, H. (1990) Export competitiveness and UK sales of Scottish manufacturers. Working paper. Scottish Enterprise, Glasgow.

Glømsrod, S. and Wei, T. (2005). "Coal cleaning: a viable strategy for reduced carbon emissions and improved environment in China?" Energy Policy 33: 525-542.

Grepperud, S. and Rasmussen, J. (2004). "A general equilibrium assessment of rebound effects.” Energy Economics 26: 261-282.

Griffin J.M. and Gregory P.R. (1976). “An intercountry translog model of energy substitution responses.” American Economic Review 66: 845-857.

Hanley N.D., McGregor P.G., Swales, J.K. and Turner, K. (2006). "The impact of a stimulus to energy efficiency on the economy and the environment: A regional computable general equilibrium analysis". Renewable Energy 31: 161-171

Hanley N.D., McGregor P.G., Swales, J.K. and Turner, K. (2009). 'Do increases in energy efficiency improve environmental quality and sustainability?" Ecological Economics 68: 692-709.

Harrigan, F., McGregor, P.G., Perman, R., Swales, J.K. and Yin, Y.P. (1991). “AMOS: A Macro-Micro Model of Scotland.” Economic Modelling 8: 424-479.

Harris, J.R. and Todaro, M. (1970). 'Migration, unemployment and development: a twosector analysis." American Economic Review 60: 126-42. 
Hertel, T.W. and Mount, T.D. (1985). "The pricing of natural resources in a regional economy." Land Economics 61: 229-243.

Kamat, R., Rose, A. and Abler, D. (1999). 'The Impact of a Carbon Tax on the Susquehanna River Basin Economy.” Energy Economics 21: 363-384.

Kemfert, C. (1998). "Estimated substitution elasticities of a nested CES production function approach for Germany.” Energy Economics 20: 249-264.

Kemfert, C. and Welsch, H. (2000). "Energy-capital-labor substitution and the economic effects of CO2 abatement: evidence for Germany." Journal of Policy Modeling 22: 641-660.

Kuper, G.H., Soest, D.P. van (2002). "Path-dependency and input substitution: implications for energy policy modelling.” Energy Economics 25: 397-407.

Layard, R., Nickell, S. and Jackman, R. (1991). Unemployment: Macroeconomic Performance and the Labour Market. Oxford University Press.

Li, P. and Rose, A. (1995). "Global warming policy and the Pennsylvania economy: A computable general equilibrium analysis.” Economic Systems Research 7: 151-171.

McGregor, P.G., Swales, J.K. and Yin, Y.P. (1996). "A long-run interpretation of regional input-output analysis.” Journal of Regional Science 36: 479-501. 
Morrison, C.J. and Berndt, Ernst R. (1981). "Short-run labor productivity in a dynamic model.” Journal of Econometrics 16: 339-366.

Naqvi, F. (1998). “A computable general equilibrium model of energy, economy and equity interactions in Pakistan.” Energy Economics 20: 347-373.

Partridge, M. and Rickman, D. 1998. Regional Computable General Equilibrium Modelling: A Survey and Critical Appraisal. International Regional Science Review, 21, 205-248.

Perroni,C. and Rutherford, T. (1995). "Regular flexibility of nested CES functions." European Economic Review 39: 335-343.

Pindych, R.S. and Rotemberg, Julio J. (1983). "Dynamic factor demands and the effect of energy price shocks.” American Economic Review 73: 1066-1079.

Prywes M. (1986). “A nested CES approach to capital-energy substitution." Energy Economics 8: 22-28.

Solow, J.L. (1987). "The capital-energy complementarity debate revisited." American Economic Review 77: 605-614

Stephan, G., Nieuwkoop, R. and Wiedmer, T. (1992). "Social incidence and economic costs of carbon limits: a computable general equilibrium analysis for Switzerland." Environmental and Resource Economics 2: 569-591. 
Turner, K. (2008) A computable general equilibrium analysis of the relative price sensitivity required to induce rebound effects in response to an improvement in energy efficiency in the UK economy, Strathclyde Discussion Papers in Economics, No. 08-07.

Turner, K. (2009). "Negative rebound and disinvestment effects in response to an improvement in energy efficiency in the UK Economy." Energy Economics 31: 648-666.

Uzawa, H. (1962). "Production Functions with Constant Elasticities of Substitution." The Review of Economic Studies 29: 291-299.

Van der Werf, E. 2008. Production functions for climate policy modeling: An empirical analysis. Energy Economics, 30: 2964-2979.

Wissema, W. and R. Dellink (2007). "AGE analysis of the impact of a carbon energy tax on the Irish economy." Ecological Economics 61: 671-683.

Zhang, Z. (1998). "Macro-economic and Sectoral Effects of Carbon Taxes: a General Equilibrium Analysis for China.” Economic Systems Research 10: 135-159. 
Sectoral breakdown of the 1999 Scottish AMOSENVI model

\begin{tabular}{|l|l|l|}
\hline & Sectors & \multicolumn{1}{|c|}{ IOC } \\
\hline 1 & Primary & $1,2.1,2.2,3.1,3.2,6.7,5$ \\
2 & Manufacturing & 8 to 84 \\
3 & Water and Construction & 87,88 \\
4 & Services & 89 to 114 \\
5 & Public Services & 116 to 123 \\
6 & Energy & $4,35,85,86$ \\
\hline
\end{tabular}




\section{TABLES}

Table 1. Summary impacts of varying the value of the elasticity of substitution between capital $(\mathrm{K})$ and labour $(\mathrm{L})$ in nesting Case $\mathrm{A}$ (\% change from base year value)

\begin{tabular}{|c|c|c|c|c|c|c|c|}
\hline \multirow{2}{*}{ 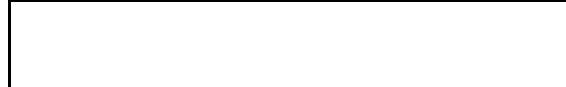 } & \multicolumn{6}{|c|}{ SR } & \multirow{2}{*}{$\frac{\mathrm{LR}}{\mathrm{ALL}}$} \\
\hline & 0.20 & 0.40 & 0.60 & 0.80 & 1.00 & 1.20 & \\
\hline GRP Income measure & 0.0154 & 0.0314 & 0.0471 & 0.0621 & 0.0761 & 0.0892 & 0.2832 \\
\hline Unemployment Rate & -0.3388 & -0.6921 & -1.0389 & -1.3688 & -1.6780 & -1.9665 & 0.0000 \\
\hline Total Employ ment & 0.0598 & 0.1221 & 0.1833 & 0.2415 & 0.2961 & 0.3470 & 0.1871 \\
\hline Real Wage after Tax & -0.0054 & -0.0054 & -0.0053 & -0.0052 & -0.0050 & -0.0049 & 0.0000 \\
\hline Households Consumption & 0.0624 & 0.0978 & 0.1322 & 0.1647 & 0.1951 & 0.2233 & 0.1297 \\
\hline Investment by Origin & 0.3015 & 0.6068 & 0.9015 & 1.1795 & 1.4389 & 1.6801 & 0.3165 \\
\hline \multicolumn{8}{|l|}{ Rate of Return to Cap. } \\
\hline PRY & 0.1067 & 0.1229 & 0.1345 & 0.1426 & 0.1481 & 0.1516 & 0.0000 \\
\hline MAN & 0.0081 & 0.0198 & 0.0291 & 0.0362 & 0.0417 & 0.0458 & 0.0000 \\
\hline $\mathrm{CON}$ & 1.3502 & 1.5179 & 1.5459 & 1.5250 & 1.4847 & 1.4368 & 0.0000 \\
\hline SER & 0.2228 & 0.2542 & 0.2730 & 0.2832 & 0.2879 & 0.2889 & 0.0000 \\
\hline PSER & 0.1470 & 0.1129 & 0.0983 & 0.0894 & 0.0830 & 0.0779 & 0.0000 \\
\hline ENE & 5.8296 & 5.2733 & 4.8128 & 4.4256 & 4.0957 & 3.8111 & 0.0000 \\
\hline Total domestic use of energy & -0.0607 & 0.0823 & 0.2048 & 0.3108 & 0.4032 & 0.4847 & 1.1978 \\
\hline Total production use of energy & 0.9372 & 1.0041 & 1.0629 & 1.1150 & 1.1612 & 1.2025 & 1.4597 \\
\hline Production use of local energy & 0.2694 & 0.4245 & 0.5566 & 0.6703 & 0.7691 & 0.8559 & 1.6880 \\
\hline Production use of RUK energy & 2.8942 & 2.7644 & 2.6605 & 2.5756 & 2.5053 & 2.4461 & 1.3886 \\
\hline Production use of ROW energy & 0.2755 & 0.2893 & 0.3035 & 0.3177 & 0.3316 & 0.3449 & 0.3558 \\
\hline Total final consumption use of energy & 0.5529 & 1.0440 & 1.4777 & 1.8620 & 2.2043 & 2.5113 & 0.5200 \\
\hline
\end{tabular}

Table 2. Summary impacts of varying the value of the elasticity of substitution between intermediates (EM) and value-added (KL) in nesting Case A (\% change from base year value)

\begin{tabular}{|c|c|c|c|c|c|c|c|}
\hline \multirow{2}{*}{ 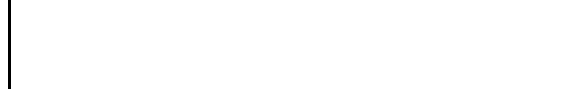 } & \multicolumn{6}{|c|}{ SR } & \multirow{2}{*}{\begin{tabular}{|l} 
LR \\
ALL \\
\end{tabular}} \\
\hline & 0.20 & 0.40 & 0.60 & $\mathbf{0 . 8 0}$ & 1.00 & 1.20 & \\
\hline GRP Income measure & 0.0552 & 0.0507 & 0.0471 & 0.0441 & 0.0415 & 0.0393 & 0.2832 \\
\hline Unemployment Rate & -1.2184 & -1.1192 & -1.0389 & -0.9723 & -0.9158 & -0.8671 & 0.0000 \\
\hline Total Employ ment & 0.2150 & 0.1975 & 0.1833 & 0.1716 & 0.1616 & 0.1530 & 0.1871 \\
\hline Real Wage after Tax & -0.0062 & -0.0057 & -0.0053 & -0.0050 & -0.0047 & -0.0044 & 0.0000 \\
\hline Households Consumption & 0.1555 & 0.1426 & 0.1322 & 0.1236 & 0.1163 & 0.1100 & 0.1297 \\
\hline Investment by Origin & 1.0682 & 0.9760 & 0.9015 & 0.8396 & 0.7872 & 0.7421 & 0.3165 \\
\hline \multicolumn{8}{|l|}{ Rate of Return to Cap. } \\
\hline PRY & 0.1314 & 0.1338 & 0.1345 & 0.1342 & 0.1331 & 0.1316 & 0.0000 \\
\hline MAN & 0.0270 & 0.0282 & 0.0291 & 0.0297 & 0.0302 & 0.0305 & 0.0000 \\
\hline $\mathrm{CON}$ & 1.9689 & 1.7317 & 1.5459 & 1.3964 & 1.2735 & 1.1706 & 0.0000 \\
\hline SER & 0.2970 & 0.2843 & 0.2730 & 0.2626 & 0.2531 & 0.2443 & 0.0000 \\
\hline PSER & 0.1014 & 0.0998 & 0.0983 & 0.0969 & 0.0956 & 0.0943 & 0.0000 \\
\hline ENE & 6.1041 & 5.3819 & 4.8128 & 4.3528 & 3.9734 & 3.6547 & 0.0000 \\
\hline Total domestic use of energy & -0.2018 & 0.0246 & 0.2048 & 0.3518 & 0.4740 & 0.5774 & 1.1978 \\
\hline Total production use of energy & 0.7656 & 0.9308 & 1.0629 & 1.1712 & 1.2615 & 1.3383 & 1.4597 \\
\hline Production use of local energy & 0.0363 & 0.3258 & 0.5566 & 0.7451 & 0.9020 & 1.0349 & 1.6880 \\
\hline Production use of RUK energy & 2.8094 & 2.7256 & 2.6605 & 2.6085 & 2.5663 & 2.5314 & 1.3886 \\
\hline Production use of ROW energy & 0.2520 & 0.2804 & 0.3035 & 0.3229 & 0.3394 & 0.3537 & 0.3558 \\
\hline Total final consumption use of energy & 1.8434 & 1.6391 & 1.4777 & 1.3470 & 1.2389 & 1.1478 & 0.5200 \\
\hline
\end{tabular}


Table 3. Summary impacts of varying the value of the elasticity of substitution between energy (E) and materials ( $M$ ) in nesting Case A (\% change from base year value)

\begin{tabular}{|c|c|c|c|c|c|c|c|}
\hline \multirow{2}{*}{$x^{2}$} & \multicolumn{6}{|c|}{ SR } & \multirow{2}{*}{\begin{tabular}{|l} 
LR \\
ALL
\end{tabular}} \\
\hline & 0.20 & 0.40 & 0.60 & 0.80 & 1.00 & 1.20 & \\
\hline GRP Income measure & 0.0471 & 0.0471 & 0.0471 & 0.0471 & 0.0471 & 0.0471 & 0.2832 \\
\hline Unemployment Rate & -1.0388 & -1.0388 & -1.0389 & -1.0390 & -1.0391 & -1.0392 & 0.0000 \\
\hline Total Employ ment & 0.1833 & 0.1833 & 0.1833 & 0.1834 & 0.1834 & 0.1834 & 0.1871 \\
\hline Real Wage after Tax & -0.0053 & -0.0053 & -0.0053 & -0.0053 & -0.0053 & -0.0053 & 0.0000 \\
\hline Households Consumption & 0.1322 & 0.1322 & 0.1322 & 0.1322 & 0.1322 & 0.1322 & 0.1297 \\
\hline Investment by Origin & 0.9018 & 0.9016 & 0.9015 & 0.9013 & 0.9011 & 0.9009 & 0.3165 \\
\hline \multicolumn{8}{|l|}{ Rate of Return to Cap. } \\
\hline PRY & 0.1343 & 0.1344 & 0.1345 & 0.1346 & 0.1347 & 0.1349 & 0.0000 \\
\hline MAN & 0.0290 & 0.0291 & 0.0291 & 0.0292 & 0.0292 & 0.0293 & 0.0000 \\
\hline $\mathrm{CON}$ & 1.5476 & 1.5468 & 1.5459 & 1.5450 & 1.5442 & 1.5433 & 0.0000 \\
\hline SER & 0.2725 & 0.2727 & 0.2730 & 0.2732 & 0.2734 & 0.2736 & 0.0000 \\
\hline PSER & 0.0980 & 0.0981 & 0.0983 & 0.0984 & 0.0986 & 0.0988 & 0.0000 \\
\hline ENE & 4.8242 & 4.8185 & 4.8128 & 4.8072 & 4.8015 & 4.7959 & 0.0000 \\
\hline Total domestic use of energy & 0.2153 & 0.2101 & 0.2048 & 0.1996 & 0.1944 & 0.1892 & 1.1978 \\
\hline Total production use of energy & 1.0806 & 1.0718 & 1.0629 & 1.0541 & 1.0454 & 1.0366 & 1.4597 \\
\hline Production use of local energy & 0.5726 & 0.5646 & 0.5566 & 0.5486 & 0.5407 & 0.5327 & 1.6880 \\
\hline Production use of RUK energy & 2.6822 & 2.6713 & 2.6605 & 2.6497 & 2.6389 & 2.6281 & 1.3886 \\
\hline Production use of ROW energy & 0.3212 & 0.3124 & 0.3035 & 0.2947 & 0.2859 & 0.2772 & 0.3558 \\
\hline Total final consumption use of energy & 1.4803 & 1.4790 & 1.4777 & 1.4765 & 1.4752 & 1.4739 & 0.5200 \\
\hline
\end{tabular}

Table 4. Summary impacts of varying the value of the elasticity of substitution between the energy-capital composite $(\mathrm{EK})$ and labour $(\mathrm{L})$ in nesting Case B (\% change from base year value)

\begin{tabular}{|c|c|c|c|c|c|c|c|}
\hline \multirow{2}{*}{ 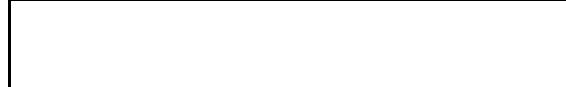 } & \multicolumn{6}{|c|}{ SR } & \multirow{2}{*}{\begin{tabular}{|l} 
LR \\
ALL
\end{tabular}} \\
\hline & 0.20 & 0.40 & 0.60 & 0.80 & 1.00 & 1.20 & \\
\hline GRP K+L & 0.0342 & 0.0418 & 0.0472 & 0.0514 & 0.0549 & 0.0578 & 0.2832 \\
\hline Unemployment Rate & -0.7541 & -0.9211 & -1.0403 & -1.1337 & -1.2104 & -1.2755 & 0.0000 \\
\hline Total Employ ment & 0.1331 & 0.1625 & 0.1836 & 0.2001 & 0.2136 & 0.2251 & 0.1871 \\
\hline Real Wage after Tax & -0.0066 & -0.0058 & -0.0053 & -0.0049 & -0.0046 & -0.0043 & 0.0000 \\
\hline Households Consumption & 0.1125 & 0.1237 & 0.1324 & 0.1395 & 0.1455 & 0.1506 & 0.1297 \\
\hline Investment by Origin & 1.1976 & 1.0119 & 0.9027 & 0.8264 & 0.7684 & 0.7218 & 0.3165 \\
\hline \multicolumn{8}{|l|}{ Rate of Return to Cap. } \\
\hline PRY & 0.1667 & 0.1479 & 0.1347 & 0.1242 & 0.1154 & 0.1078 & 0.0000 \\
\hline MAN & 0.0353 & 0.0319 & 0.0292 & 0.0269 & 0.0249 & 0.0231 & 0.0000 \\
\hline CON & 3.5384 & 2.1723 & 1.5479 & 1.1916 & 0.9621 & 0.8020 & 0.0000 \\
\hline SER & 0.3835 & 0.3175 & 0.2733 & 0.2406 & 0.2151 & 0.1946 & 0.0000 \\
\hline PSER & 0.1833 & 0.1287 & 0.0984 & 0.0790 & 0.0655 & 0.0556 & 0.0000 \\
\hline ENE & 5.0568 & 4.9307 & 4.8185 & 4.7141 & 4.6154 & 4.5212 & 0.0000 \\
\hline Total domestic use of energy & 0.2376 & 0.2188 & 0.2082 & 0.2010 & 0.1956 & 0.1912 & 1.1978 \\
\hline Total production use of energy & 1.1503 & 1.1007 & 1.0643 & 1.0340 & 1.0073 & 0.9829 & 1.4597 \\
\hline Production use of local energy & 0.6281 & 0.5872 & 0.5604 & 0.5398 & 0.5226 & 0.5076 & 1.6880 \\
\hline Production use of RUK energy & 2.8141 & 2.7277 & 2.6563 & 2.5925 & 2.5337 & 2.4785 & 1.3886 \\
\hline Production use of ROW energy & 0.3321 & 0.3156 & 0.3037 & 0.2939 & 0.2853 & 0.2776 & 0.3558 \\
\hline Total final consumption use of energy & 1.8906 & 1.6204 & 1.4796 & 1.3875 & 1.3192 & 1.2647 & 0.5200 \\
\hline
\end{tabular}


Table 5. Summary impacts of varying the value of the elasticity of substitution between energy ( $\mathrm{E})$ and capital $(\mathrm{K})$ in nesting Case $B$ ( $\%$ change from base year value)

\begin{tabular}{|c|c|c|c|c|c|c|c|}
\hline \multirow[t]{2}{*}{ Changing elast. Parameter in E+K } & \multicolumn{6}{|c|}{ SR } & \multirow{2}{*}{\begin{tabular}{|l} 
LR \\
ALL \\
\end{tabular}} \\
\hline & 0.20 & 0.40 & 0.60 & 0.80 & 1.00 & 1.20 & \\
\hline GRP K+L & 0.0275 & 0.0378 & 0.0472 & 0.0562 & 0.0653 & 0.0750 & 0.2832 \\
\hline Unemployment Rate & -0.6068 & -0.8333 & -1.0403 & -1.2400 & -1.4407 & -1.6531 & 0.0000 \\
\hline Total Employ ment & 0.1071 & 0.1470 & 0.1836 & 0.2188 & 0.2542 & 0.2917 & 0.1871 \\
\hline Real Wage after Tax & -0.0051 & -0.0052 & -0.0053 & -0.0055 & -0.0057 & -0.0060 & 0.0000 \\
\hline Households Consumption & 0.0874 & 0.1108 & 0.1324 & 0.1536 & 0.1751 & 0.1981 & 0.1297 \\
\hline Investment by Origin & 0.2780 & 0.5771 & 0.9027 & 1.2613 & 1.6592 & 2.1131 & 0.3165 \\
\hline \multicolumn{8}{|l|}{ Rate of Return to Cap. } \\
\hline PRY & 0.0832 & 0.1111 & 0.1347 & 0.1560 & 0.1761 & 0.1964 & 0.0000 \\
\hline MAN & 0.0039 & 0.0176 & 0.0292 & 0.0396 & 0.0494 & 0.0592 & 0.0000 \\
\hline $\mathrm{CON}$ & 0.6822 & 1.1472 & 1.5479 & 1.9135 & 2.2625 & 2.6164 & 0.0000 \\
\hline SER & 0.1671 & 0.2235 & 0.2733 & 0.3199 & 0.3655 & 0.4128 & 0.0000 \\
\hline PSER & 0.0620 & 0.0839 & 0.0984 & 0.1090 & 0.1174 & 0.1249 & 0.0000 \\
\hline ENE & 6.5131 & 5.5359 & 4.8185 & 4.2728 & 3.8480 & 3.5055 & 0.0000 \\
\hline Total domestic use of energy & -0.5286 & -0.1133 & 0.2082 & 0.4698 & 0.6914 & 0.8899 & 1.1978 \\
\hline Total production use of energy & 0.4564 & 0.7958 & 1.0643 & 1.2885 & 1.4840 & 1.6650 & 1.4597 \\
\hline Production use of local energy & -0.3816 & 0.1489 & 0.5604 & 0.8962 & 1.1813 & 1.4377 & 1.6880 \\
\hline Production use of RUK energy & 2.6569 & 2.6467 & 2.6563 & 2.6813 & 2.7197 & 2.7719 & 1.3886 \\
\hline Production use of ROW energy & 0.1978 & 0.2532 & 0.3037 & 0.3522 & 0.4007 & 0.4518 & 0.3558 \\
\hline Total final consumption use of energy & 0.5545 & 1.0350 & 1.4796 & 1.9133 & 2.3526 & 2.8214 & 0.5200 \\
\hline
\end{tabular}

Table 6. Summary impacts of varying the value of the elasticity of substitution between value-added with energy (LKE) and materials $(M)$ in nesting Case $B$ (\% change from base year value)

\begin{tabular}{|c|c|c|c|c|c|c|c|}
\hline \multirow[t]{2}{*}{ Changing elast. Parameter in VA+INT } & \multicolumn{6}{|c|}{ SR } & \multirow{2}{*}{\begin{tabular}{|l} 
LR \\
ALL \\
\end{tabular}} \\
\hline & 0.20 & 0.40 & 0.60 & 0.80 & 1.00 & 1.20 & \\
\hline GRP K+L & 0.0511 & 0.0490 & 0.0472 & 0.0455 & 0.0439 & 0.0424 & 0.2832 \\
\hline Unemployment Rate & -1.1261 & -1.0813 & -1.0403 & -1.0026 & -0.9679 & -0.9358 & 0.0000 \\
\hline Total Employ ment & 0.1987 & 0.1908 & 0.1836 & 0.1769 & 0.1708 & 0.1651 & 0.1871 \\
\hline Real Wage after Tax & -0.0057 & -0.0055 & -0.0053 & -0.0051 & -0.0050 & -0.0048 & 0.0000 \\
\hline Households Consumption & 0.1433 & 0.1376 & 0.1324 & 0.1276 & 0.1232 & 0.1192 & 0.1297 \\
\hline Investment by Origin & 0.9735 & 0.9366 & 0.9027 & 0.8712 & 0.8420 & 0.8148 & 0.3165 \\
\hline \multicolumn{8}{|l|}{ Rate of Return to Cap. } \\
\hline PRY & 0.1353 & 0.1352 & 0.1347 & 0.1339 & 0.1328 & 0.1315 & 0.0000 \\
\hline MAN & 0.0279 & 0.0286 & 0.0292 & 0.0296 & 0.0300 & 0.0302 & 0.0000 \\
\hline $\mathrm{CON}$ & 1.7649 & 1.6500 & 1.5479 & 1.4566 & 1.3746 & 1.3006 & 0.0000 \\
\hline SER & 0.2880 & 0.2805 & 0.2733 & 0.2664 & 0.2598 & 0.2535 & 0.0000 \\
\hline PSER & 0.0999 & 0.0992 & 0.0984 & 0.0976 & 0.0969 & 0.0961 & 0.0000 \\
\hline ENE & 5.2777 & 5.0376 & 4.8185 & 4.6178 & 4.4333 & 4.2629 & 0.0000 \\
\hline Total domestic use of energy & 0.2264 & 0.2169 & 0.2082 & 0.2003 & 0.1929 & 0.1861 & 1.1978 \\
\hline Total production use of energy & 1.1625 & 1.1112 & 1.0643 & 1.0213 & 0.9817 & 0.9450 & 1.4597 \\
\hline Production use of local energy & 0.6115 & 0.5848 & 0.5604 & 0.5380 & 0.5174 & 0.4983 & 1.6880 \\
\hline Production use of RUK energy & 2.9049 & 2.7750 & 2.6563 & 2.5474 & 2.4473 & 2.3547 & 1.3886 \\
\hline Production use of ROW energy & 0.3296 & 0.3161 & 0.3037 & 0.2922 & 0.2817 & 0.2719 & 0.3558 \\
\hline Total final consumption use of energy & 1.6195 & 1.5463 & 1.4796 & 1.4188 & 1.3629 & 1.3115 & 0.5200 \\
\hline
\end{tabular}


Table 7. Sensitivity analysis: random variation in values attached to elasticities at each nest within Case A and Case B

\begin{tabular}{|l|c|c|c|c|c|c|c|c|}
\hline & GDP & SD & GDP + SD & GDP - SD & $\begin{array}{c}\text { Use of } \\
\text { energy in } \\
\text { production }\end{array}$ & SD & Energy + SD & Energy - SD \\
\hline A. EM-LK & 0.051 & 0.014 & 0.065 & 0.037 & 1.118 & 0.167 & 1.285 & 0.951 \\
\hline B. L-KE & 0.051 & 0.011 & 0.062 & 0.040 & 1.117 & 0.311 & 1.428 & 0.806 \\
\hline
\end{tabular}

SD: standard deviation 


\section{FIGURES}

Figure 1: Example Of A CES Hierarchical/Nested Production Function

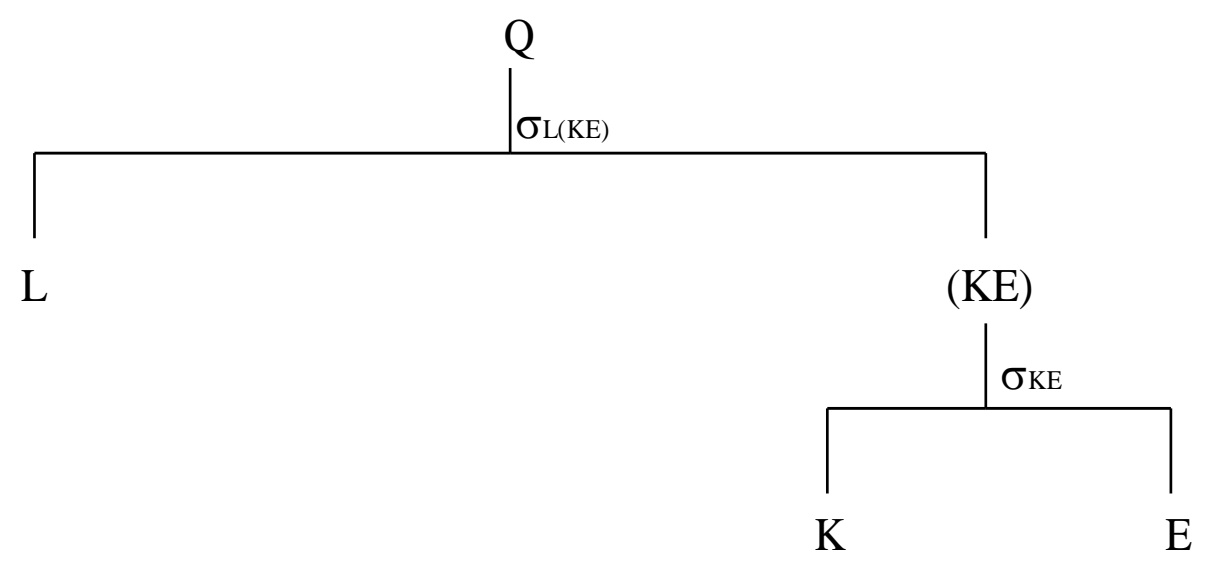


Figure 2. Alternative specifications of the KLEM production function in AMOSENVI for each production sector, $i$

Case A. Energy as an intermediate $-E M+K L$

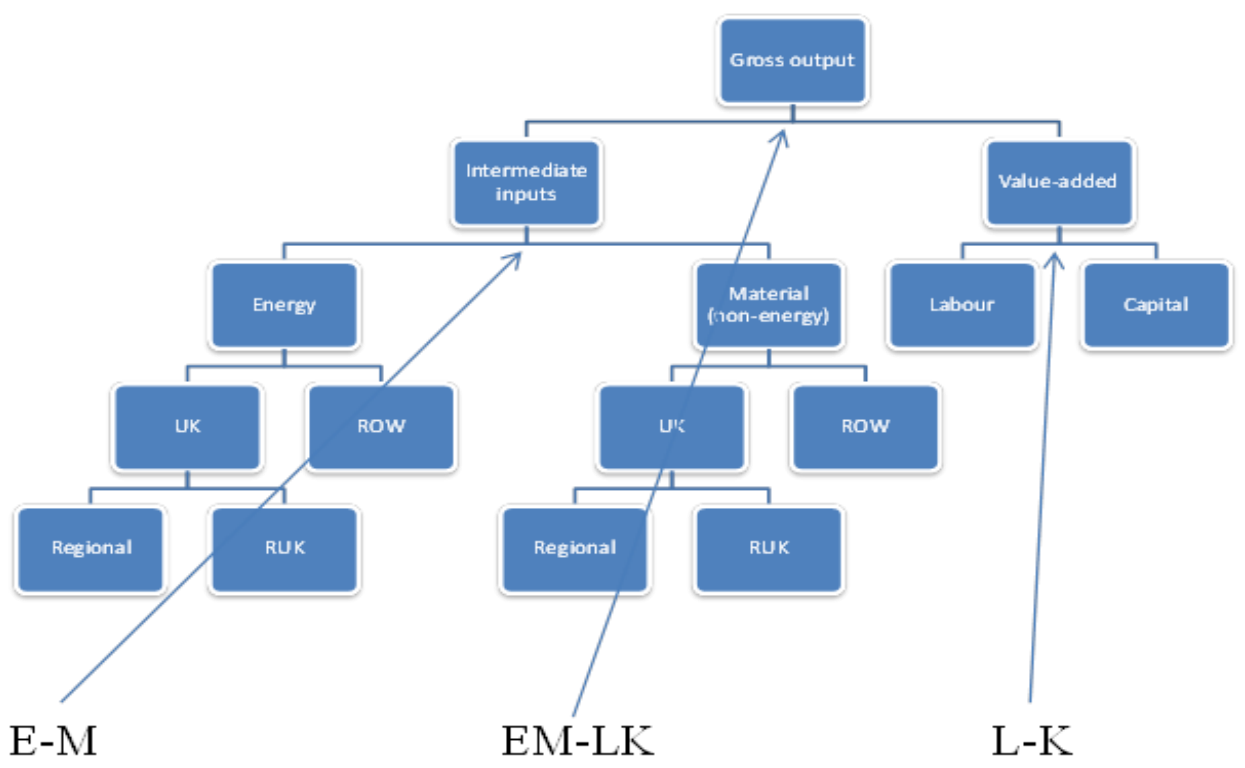

Case B. Energy in value-added $-L+K E$

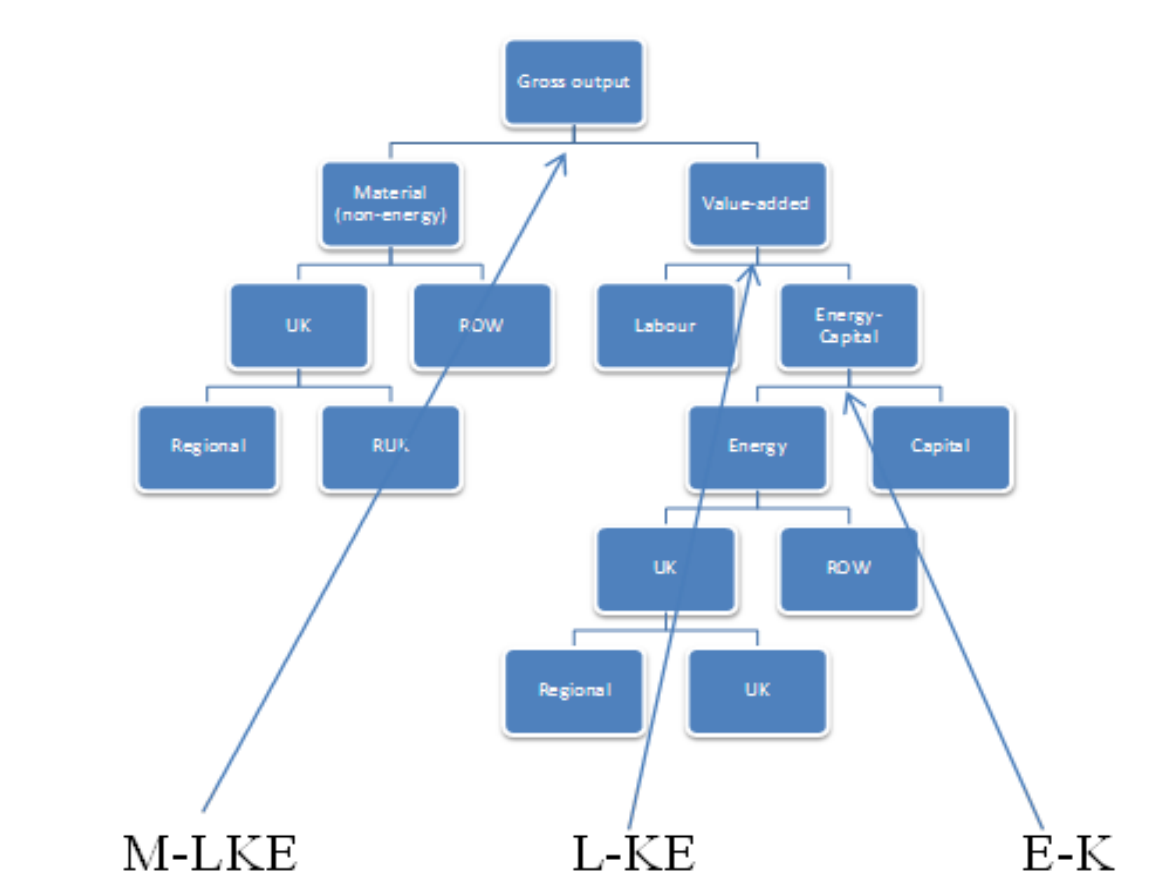



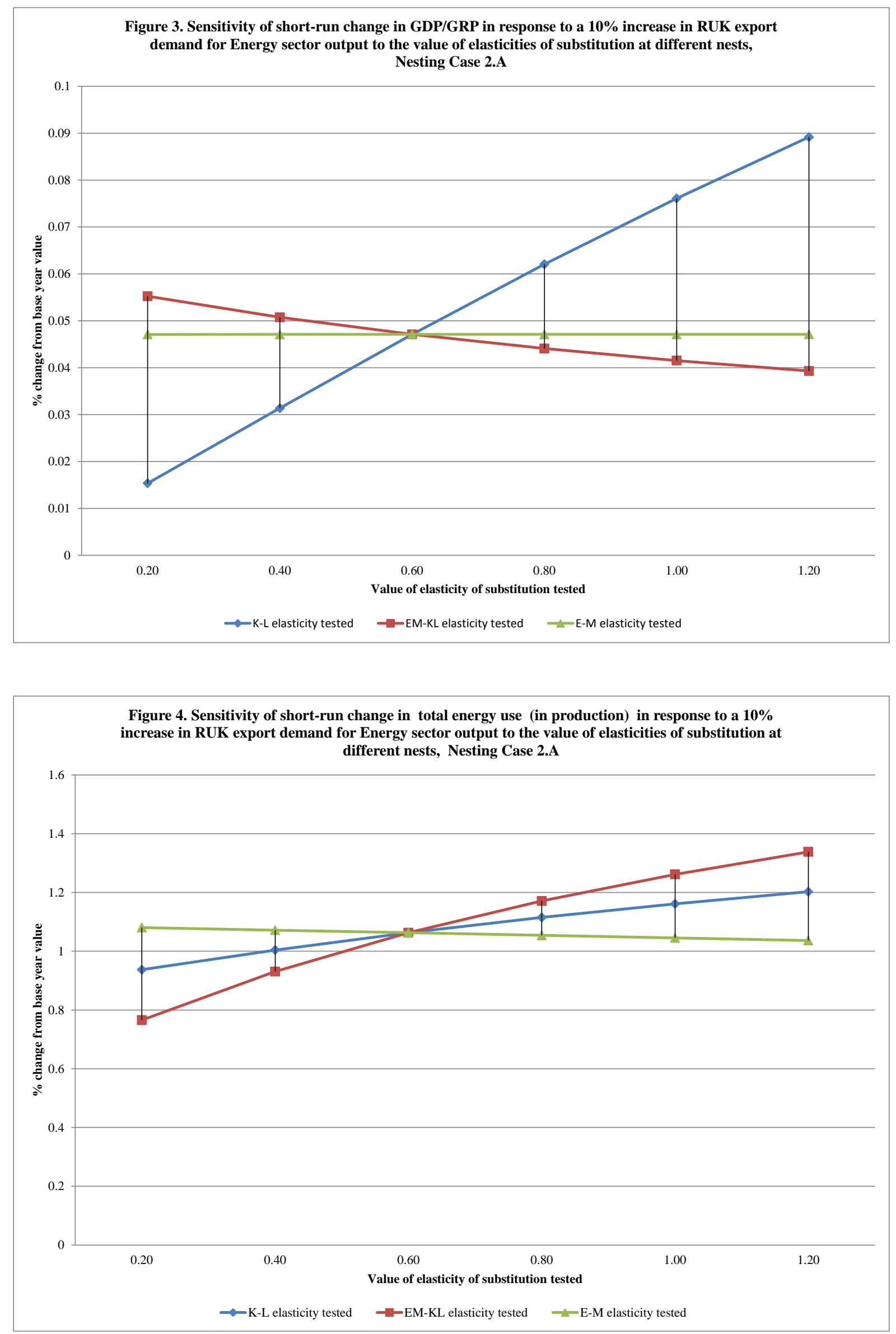

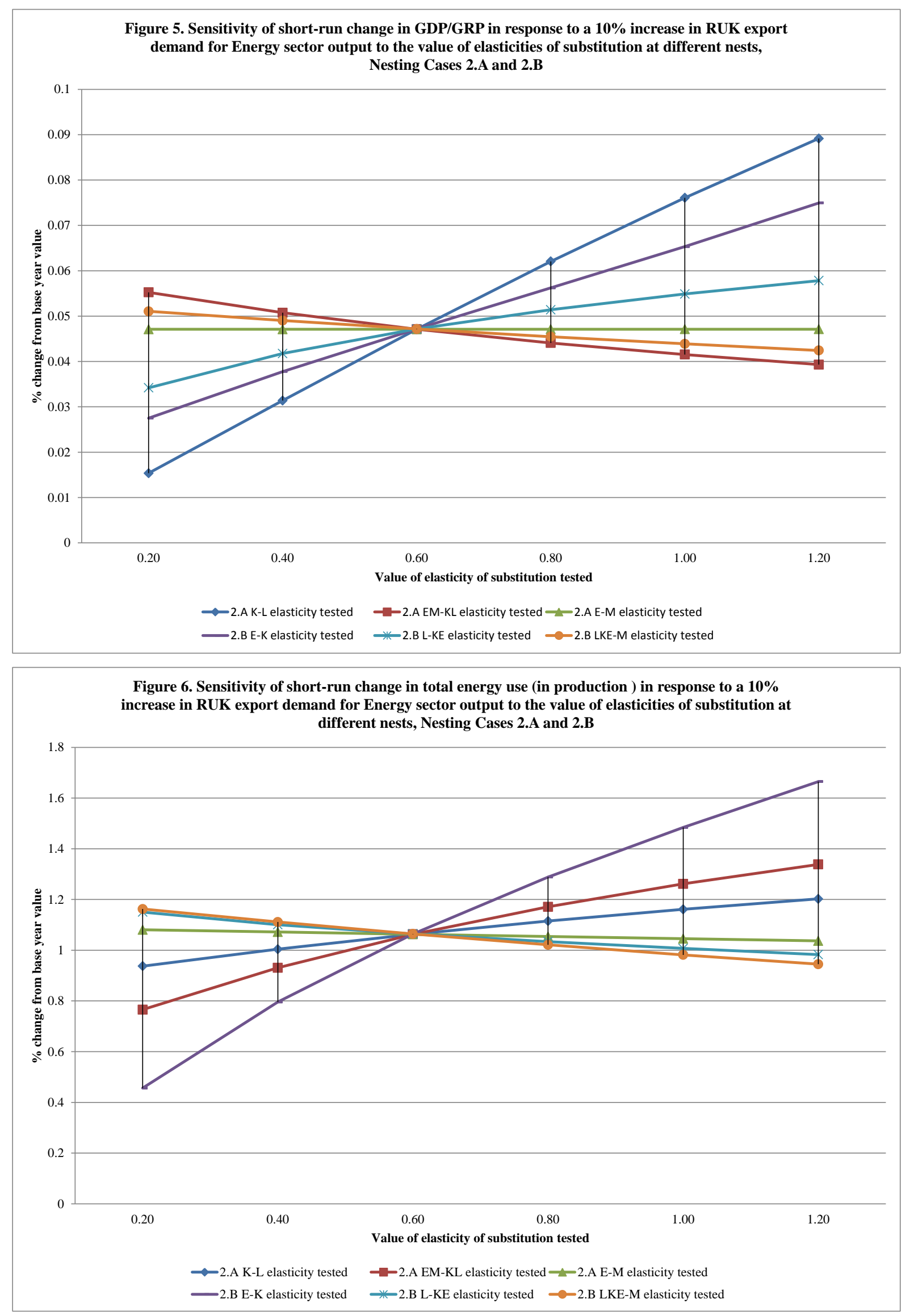